\title{
The first cancer patient with COVID-19 in Slovakia
}

\author{
Prvý pacient s COVID-19 na Slovensku
}

\author{
'Slopovský J. ' , Šálek T. ${ }^{1}$, Pazderová N. ', Zomborská E. ', Makovník M. ', Palacka P. ${ }^{1}$, Horniczká K. ${ }^{2}$, \\ Stankovič I. ${ }^{2}$, Pörsök Š. ${ }^{1}$ \\ $12^{\text {nd }}$ Department of Oncology, Faculty of Medicine, Comenius University, Bratislava, Slovak Republic \\ 2 Department of Infectiology and Geographical Medicine, University Hospital, Bratislava, Slovak Republic
}

\begin{abstract}
Summary
Background: In December 2019 a new strain of coronavirus SARS-CoV-2 has emerged and affected health care worldwide. Patients with cancer and other comorbidities are at increased risk for adverse outcomes in this infection. Case: In this case report we present a 75-year-old patient with a localized gastric adenocarcinoma, currently treated by perioperative chemotherapy regimen, who had an rT-PCR proven novel coronavirus SARS-CoV- 2 infection. Laboratory and radiologic assessments were performed in order to assess disease severity; however, the findings were not altered in accordance with the findings associated with COVID-19 disease. Results: On the first hospital day the patient had a low grade fever with chills. Subsequently a pharmacological therapy with hydroxychloroquine and azithromycin was started. After pharmacologic and symptomatic treatment, the patient was reassessed for SARS-CoV-2, with negative results. At discharge, the patient was ordered a 14-day mandatory quarantine. After 57 days of follow-up, the patient underwent a new rapid antibody test by Acro Biotech inc., which gave negative results for IgM and IgG. Conclusion: An infection with SARS-CoV-2 is associated with a more severe disease in patients with comorbidities and cancer; however, this case patient had a mild course of COVID-19 disease. The aim of this case report is to share the information on the clinical course and outcomes of a patient with malignancy. Rapid spreading of information is crucial in the management of COVID-19.
\end{abstract}

\section{Key words}

gastric cancer - SARS-CoV-2 - COVID-19 - chemotherapy - treatment

\section{Súhrn}

Východiská: Infekcia novým SARS-CoV-2 predstavuje vysoké riziko pre komorbídných pacientov a pacientov liečiacich sa na onkologické ochorenia. Prípad: $V$ tejto kazuistike uvádzame 75-ročného pacienta s lokalizovaným adenokarcinómom žalúdka, ktorý je v súčasnosti liečený perioperačným cytostatickým režimom. Pre kontakt s rodinným členom, ktorý cestoval v tom čase do rizikovej krajiny, bolo realizované rT-PCR, s pozitívnym výsledkom na prítomnost' SARS-CoV-2. Pacientovi boli následne realizované laboratórne a rádiologické vyšetrenia s cielom posúdit' závažnost' ochorenia, avšak nálezy neboli v súlade s nálezmi spojenými s ochorením COVID-19. Výsledky: U pacienta bol priebeh infekcie bez výraznejších komplikácií. Počas hospitalizácie bol zaznamenaný jeden výstup teploty s miernou zimnicou a kašlom. Následne bola zahájená farmakoterapia s použitím hydroxychlorochínu v kombinácii s azitromycínom. Po liečbe došlo k zlepšeniu stavu. Počas desiateho dňa hospitalizácie bol zopakovaný test na prítomnost' RNA vírusu SARS-CoV-2, pričom výsledky boli negatívne. Na detekciu protilátok bol použitý nový test od firmy Acro Biotech inc., ktorého výsledky boli 57 dní po ukončení hospitalizácie tak isto negatívne. Pacient je od vtedy bez tažkostí v zmysle príznakov ochorenia COVID-19. Záver: Aj napriek komorbiditám a aktívnej protinádorovej liečbe bol priebeh ochorenia COVID-19 u prezentovaného pacienta mierny. Rýchla diagnostika a následne liečba tohto ochorenia bola pravdepodobne aj $v$ tomto prípade dôvodom mierneho priebehu ochorenia a je základom dobrého manažmentu pacientov s infekciou SARS-CoV-2.

Key words

gastric cancer - SARS-CoV-2 - COVID-19 - chemotherapy - treatment

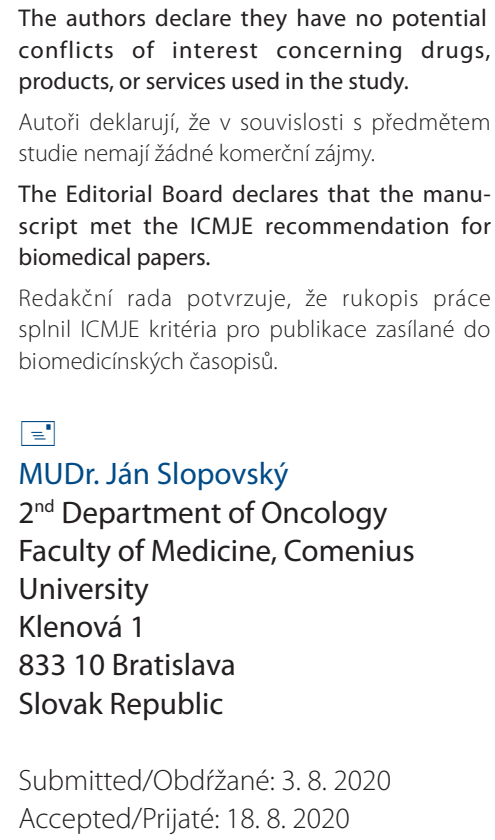

The authors declare they have no potential conflicts of interest concerning drugs, products, or services used in the study.

Autoři deklarují, že $v$ souvislosti s předmětem studie nemaji žádné komerční zájmy.

The Editorial Board declares that the manuscript met the ICMJE recommendation for biomedical papers.

Redakční rada potvrzuje, že rukopis práce splnil ICMJE kritéria pro publikace zasílané do biomedicínských časopisů

MUDr. Ján Slopovský

$2^{\text {nd }}$ Department of Oncology

Faculty of Medicine, Comenius

University

Klenová 1

83310 Bratislava

Slovak Republic

Submitted/Obdŕžané: 3. 8. 2020

Accepted/Prijaté: 18. 8. 2020

doi: 10.14735/amko2020386 


\section{Introduction}

Since December 2019, when the first infection with a novel coronavirus (SARS-CoV-2) was described in Wuhan, China, the virus had spread rapidly across all continents and has affected both the medical and economic sectors of the countries. SARS-CoV-2 infection and the subsequent outbreak of COVID-19 disease currently represents a global clinical and economic challenge, therefore a prompt understanding and investigation of this infection is needed to prevent it from further spreading and endangering populations of patients at risk, such as cancer patients and patients with various comorbidities [1].

The aim of this case report is to describe the first case of SARS-CoV-2 infection in a patient with malignancy at the National Cancer Institute (NCI) in Bratislava, Slovakia. This case represents the importance and necessity of close coordination between physicians and public health care authorities, as well as rapid spreading of clinical information relevant to the care of cancer patients with this infection. The antibody test was performed 57 days after the diagnosis of COVID-19, which represents a new testing method for antibody response to SARS-CoV-2 and does not yet represent a standard procedure.

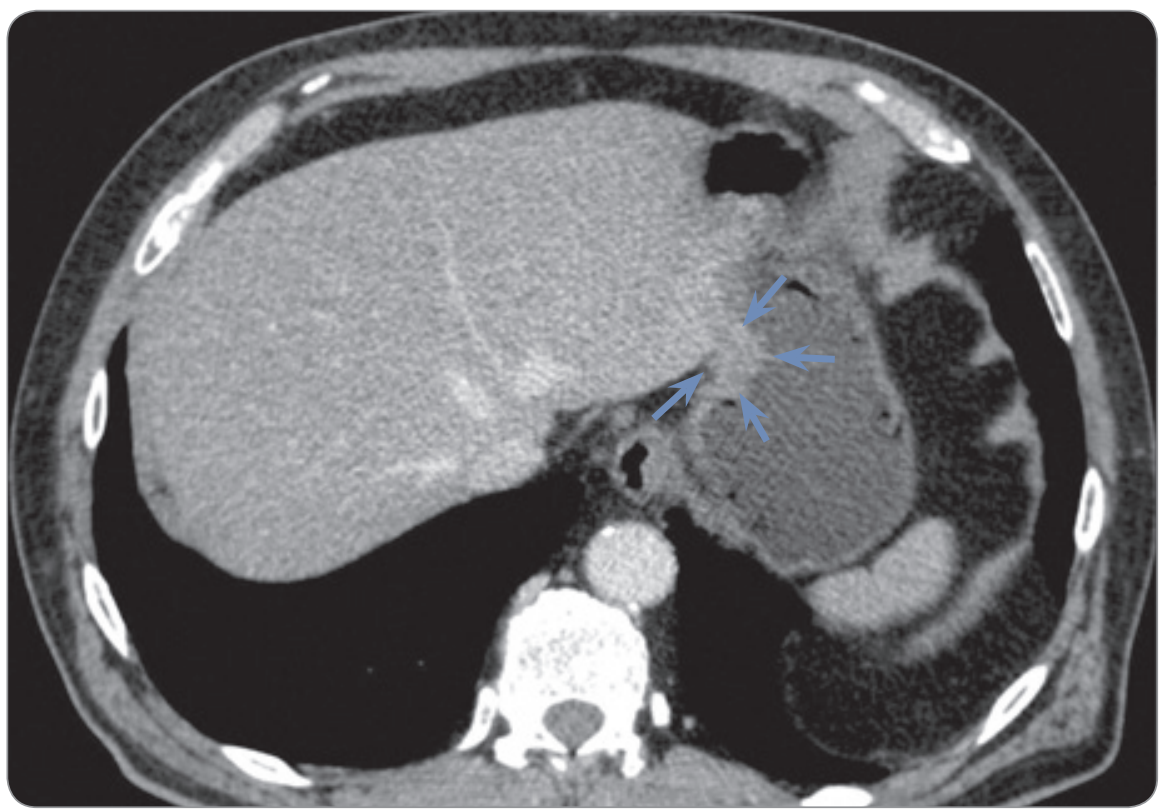

Fig. 1. An axial contrast-enhanced CT image at the level of the abdomen shows tumour of the gastric fundus (blue arrows).

\section{Case report}

On $19^{\text {th }}$ March 2020, a 75-year-old male was admitted to the 2nd Department of Oncology, Faculty of Medicine, Comenius University, Bratislava, Slovakia, for continuing his anticancer therapy.

Upon arrival at the department, the patient went through a separation filter and completed a questionnaire on exposures and symptoms targeting COVID-19. Subsequently, he was admitted to the outpatient clinic for further evaluation of admission for continuing his anticancer therapy. He was then examined by his attending physicians, while adhering to the prescribed epidemiological measures from both the physicians and the patient. Subsequently, the patient was oriented to the admission at an inpatient clinic, where he was examined and admitted in accordance with epidemiological measures. During hospitalization, the patient confessed to his roommate that he had been brought to the hospital by his son who works in Austria, where he had been last time a week ago. For this reason, the room on which he stayed was closed and a strict epidemiological regime was introduced. Nasopharyngeal and oropharynx swabs were taken from both the patient and his roommate according to clinical procedures. The results were evaluated by
rRT-PCR (reverse transcription - polymerase chain reaction) next day as positive for SARS-CoV-2 infection. The patient was subsequently transferred to the Department of Infectology and Geographical Medicine, University Hospital in Bratislava for further assessment and treatment. Doctors, nurses, and other health care professionals who came into contact with the patient were tested for SARS-CoV-2 infection 3 days later and the results came back as negative, but the health care professionals were ordered to stay in preventive quarantine for 14 days.

The patient, a 75-year-old male, is currently treated at $\mathrm{NCl}$ for gastric adenocarcinoma, T3NOMO, stage II, grade 2 (Fig. 1) and he was admitted for his 2nd cycle of perioperative chemotherapy regimen consisted of modified FOLFOX6 (5-fluorouracil, levofolic, oxaliplatin). Apart of his malignancy, the patient is treated for primary hypertension ESC/ESH 3 (European Society of Cardiology/European Society of Hypertension), hypertriglyceridemia, hypercholesterolemia. He is a former smoker for 40 years, before that he smoked approximately 10 cigarettes a day and drinks alcohol approx. every 2 days (beer or liqueur or both).

During hospitalization, the patient did not show any symptoms associated with SARS-CoV-2 infection apart of dry cough, which he said he occasionally had, especially in the morning. The physical examination showed a temperature of $36^{\circ} \mathrm{C}$, blood pressure of $185 / 73 \mathrm{~mm} \mathrm{Hg}$ and pulse $55 / \mathrm{min}$. His lung auscultations were clear and heart auscultation showed a moderate systolic murmur. Laboratory test results did not show any discrepancies except a normochromic normocytic anaemia; however, CRP and procalcitonin were not assessed at admission. Subsequently, when transferred to the Department of Infectiology and Geographical Medicine, the patient was complaining of chills, cough, and a mild fever of $37.3^{\circ} \mathrm{C}$, while he was normoxic and hemodynamically stable. In his laboratory results the patient had anaemia; inflammatory markers were not elevated, other parameters were within normal range. An anteroposterior chest radiograph (Fig. 2) was 
taken on hospital day 1 , while the patient was lying, which showed nonspecific and slightly increased perihilar vessel markings only, but no other abnormalities. However, due to the recumbent position of the patient, this could be a normal finding. During his hospitalization tonsillar swabs were taken, which showed a massive Staphylococcus aureus presence. Also, a complex assessment for respiratory viruses was performed and the patient was tested for the respiratory-syncytial virus (Ag-immunochromatography), influenza virus $A$ and $B$ (Ag- immunochromatography), and adenovirus (Ag-immunochromatography), with negative results. Subsequently, the patient was started on hydroxychloroquine $400 \mathrm{mg}$ twice a day on hospital day 1 and $200 \mathrm{mg}$ twice a day the subsequent days. In addition to hydroxychloroquine the patient has received azithromycin $500 \mathrm{mg}$ once a day on hospital day 1 and $250 \mathrm{mg}$ once a day for 10 days while he was continuing his chronic medication.

His condition was improving and the patient did not have fever or respiratory difficulties since his admission. The patient was hospitalized for 10 days. On a followup chest ray, there were no abnormalities and his follow-up SARS-CoV-2 swabs were negative on hospital day 10 . The patient was discharged to home care, with mandatory quarantine for 14 days. On follow up on $15^{\text {th }}$ May 2020 , he was tested for antibodies with negative results for $\operatorname{lgM}$ and $\lg G$, respectively.

\section{Specimen collection}

Clinical samples for SARS-CoV-2 testing were taken according to the instructions of the Chief Public Health Officer of the Slovak Republic (2nd update). Nasopharyngeal and oropharyngeal swabs were collected using two cotton swabs. Individual sterile swabs were placed in a common tube containing $2-3 \mathrm{~mL}$ of viral delivery medium. The samples were taken on hospital day 1 at $\mathrm{NCl}$, subsequently on hospital day 10 ( $1^{\text {st }}$ April 2020) at the University Hospital Bratislava. The health care professionals were tested on day 4 after the initial exposure. A new rapid antibody test was performed on $15^{\text {th }}$ May 2020, which uses im-

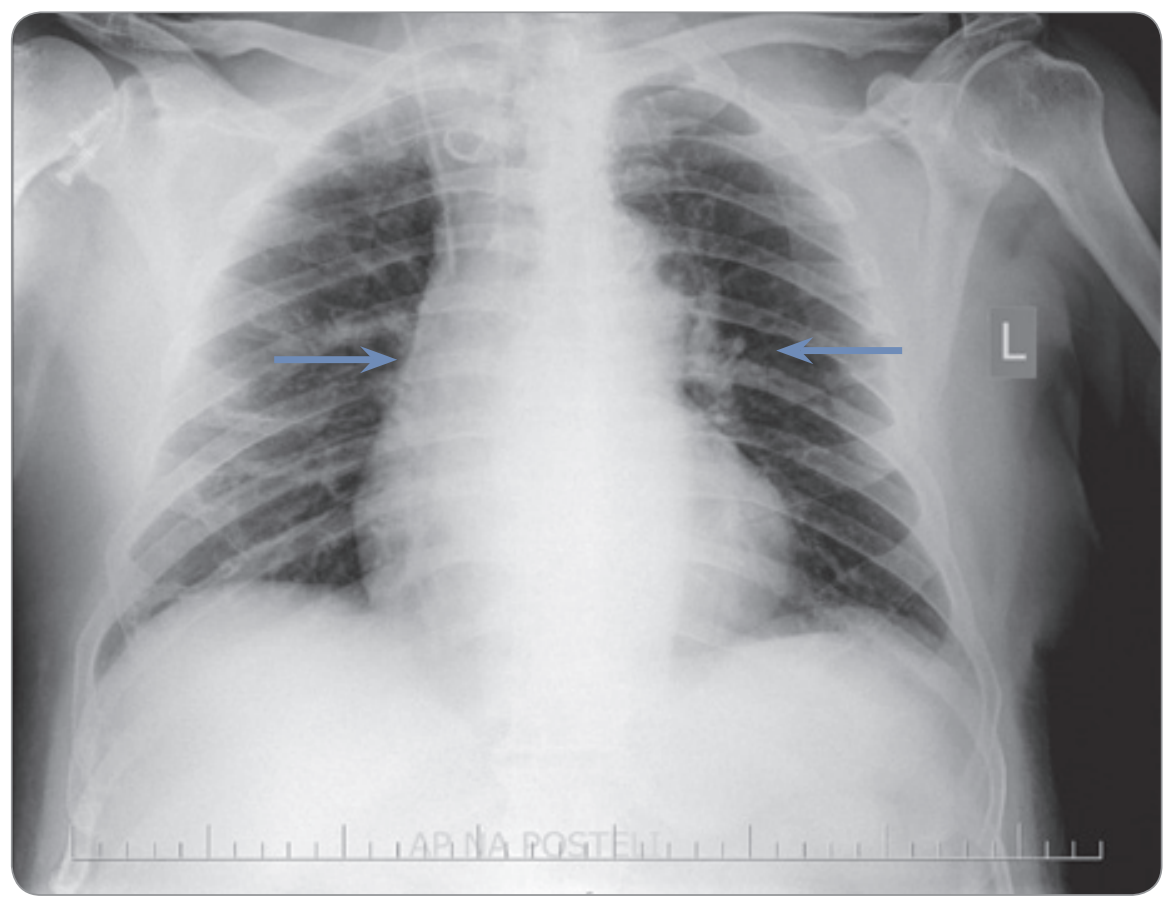

Fig. 2. A chest radiograph in an antero-posterior position with the patient in a recumbent position; non-specific slightly increased perihilar vessel markings (blue arrows) are visible.

munochromatography to measure IgG and IgM, Acro Rapid Test, Acro Biotech inc. (USA) [2].

\section{Discussion}

This is the first report of a cancer patient with COVID-19 in Slovakia. This case underlines how subtle the infection can be and shows the necessity for better understanding of its transmission dynamics and full spectrum its of clinical symptoms.

A complete SARS-CoV-2 genome sequence was published via community resources on $10^{\text {th }}$ January $(\mathrm{Wu}$ han-Hu-1, GenBank, accession number MN9089473), followed by other genome sequences published on $12^{\text {th }}$ January. Subsequently, viral RNA assays using rRT-PCR were developed. In Slovakia, a protocol published by Corman et al [4] is used. The highest sensitivity was measured for $E$ gene (an envelope) with $R d R p$ gene (RNA-dependent RNA-polymerase) used for confirmation. Therefore, if E gene is present but not confirmed by RdRp gene measurement, the results are considered negative.

An increasing amount of data suggests that patients with cancer have an increased risk for severe outcomes when infected with SARS-CoV-2, especially the patients with lung and hematologic malignancies. One multi-centre prospective study carried out in Wuhan, China, assessed 105 patients with cancer and confirmed COVID-19 and compared them to a control group of 536 of non-cancer patients. The patients with malignancies had higher observed death rate odds ratio (OR) of 2.34 as well as higher rates of ICU admission [5]. A retrospective analysis in the New York City evaluated 5,688 patients of whom 334 had cancer (6\%). The patients with cancer had a significantly higher risk for intubation compared to patients without cancer - relative risk (RR) 1.76, although mortality rates did not differ according to the age in cancer patients [6].

This case-report patient with gastric adenocarcinoma had been in a close contact with his son, currently employed in Austria, which had approximately 500 confirmed cases of COVID-19 at the time. Neither his son nor any other family members had any symptoms pointing toward SARS-CoV-2 infection and were tested negative, therefore the source of the infection of our patient 
is unknown. The SARS-CoV-2 virus is well known for person-to-person transmission [7-9]; a potential of faecal-oral transmission was also described [10].

At follow-up, the patient was tested for antibodies using an Acro rapid test; however, neither IgG nor IgM antibodies were positive. In a recent study, the antibodies were measured in plasma of 173 patients with SARS-CoV-2; the median seroconversion time for total antibodies (Ab), IgM and Ig $G$ were on day 11 , 12 and 14, respectively. Higher titres for total Ab were associated with worse clinical prognosis $(P=0.006)$ [11]. One retrospective analysis showed positive lgG antibodies over 48 days [12]. There is still a lack of understanding of the antibody response dynamics for SARS-CoV-2, therefore studies assessing antibody responses with longer-follow up are necessary for the understanding of negative results for antibodies of our case patient.

Although this case report showed very subtle symptoms specific for COVID-19 disease, a lack of robust symptoms does not rule out an infection with the novel coronavirus. It was shown that some patients are asymptomatic carriers [13], although exact numbers are still unknown. This patient initially presented with mild cough and low grade fever and chills for one day, there was no evidence of interstitial pneumonia on his chest radiography or altered laboratory results; however, some cases initially presented with the same symptoms later progressed into severe pneumonia, acute respiratory distress syndrome (ARDS) and respiratory failure, including fatal outcomes [14].

The age and various comorbidities are known risk factors for adverse outcomes in COVID-19 infection [14]. Our patient is 75 years old, has various cardiovascular comorbidities and is actively treated for his malignancy; however, his comorbidities did not seem to affect the course of his infection, possibly due to low viral load, which was linked to mild or moderate clinical course of the disease [16]. In-house rT-PCR is used in Slovak Repub- lic [4], for this protocol the rate of false positive results were zero; however, one meta-analysis of external quality assessments of RT-PCR assays of RNA viruses showed an estimate of the range of false positive rates for SARS-CoV-2 of 0-16.7\% [1], although exact numbers probably differ in each commercially available tests.

At that time, a pharmacological standard of the care in Slovakia was azithromycin with hydroxychloroquine, which was also administered to this patient. For the optimal treatment, there is still a lack of data. Chloroquine and hydroxychloroquine were shown to inhibit in vitro replication of the virus [18]. One study showed that the addition of azithromycin to hydroxychloroquine significantly reduced viral load measured by rT-PCR at day 6 post-inclusion compared to hydroxychloroquine solo [19]; however, the results of this study should be evaluated with caution due to methodological discrepancies and small sample size. Both azithromycin and hydroxychloroquine were associated with qTC prolongation and therefore should be used with caution.

\section{Conclusion}

Herein, we present a first case report of a cancer patient with COVID-19 in Slovakia. The course of the disease was mild with subtle symptoms. Prompt detection of infection with SARS-CoV-2 was crucial in early treatment initiation and rapid resolution of the disease, which enabled the patient to further continue his anti-cancer therapy. The patient was tested for IgM and IgG antibodies using a new experimental antibody assay by Acro Biotech inc., which does not represent a standard testing method.

\section{References}

1. Chow N, Fleming-Dutra K, Gierke R et al. Preliminary estimates of the prevalence of selected underlying health conditions among patients with coronavirus disease 2019 - United States, February 12-March 28 2020. Morb Mortal Wkly Rep 2020; 69(13): 382-386. doi: 10.15585/MMWR.MM6913E2.

2. Rapid Tests, Acro Biotech, Inc. [online]. Available from: https://www.acrobiotech.com/.
3. Novel 2019 coronavirus genome. [online]. Available from: http://virological.org/t/novel-2019-coronavirus-genome/319.

4. Corman VM, Landt $O$, Kaiser $M$ et al. Detection of 2019 novel coronavirus (2019-nCoV) by real-time RT-PCR. Eurosurveillance 2020; 25(3): 2000045. doi: 10.2807/15607917.ES.2020.25.3.2000045

5. Dai M, Liu D, Liu M et al. Patients with cancer appear more vulnerable to SARS-COV-2: a multi-center study during the COVID-19 outbreak. Cancer Dis CoV-2020. [in press]. doi: 10.1158/2159-8290.CD-20-0422.

6. Miyashita H, Mikami T, Chopra N et al. Do patients with cancer have a poorer prognosis of COVID-19? An Experience in New York City. Ann Oncol 2020. [in press]. doi: 10.1016/j.annonc.2020.04.006

7. Liu J, Liao X, Qian S et al. Community transmission of severe acute respiratory syndrome coronavirus 2, Shenzhen, China, 2020. Emerg Infect Dis 2020; 26(6): 1320 1323. doi: 10.3201/eid2606.200239.

8. Chan JF, Yuan S, Kok KH et al. A familial cluster of pneumonia associated with the 2019 novel coronavirus indicating person-to-person transmission: a study of a family cluster. Lancet 2020; 395(10223): 514-523. doi: 10.1016/S0140-6736(20)30154-9.

9. Li Q, Guan X, Wu P et al. Early transmission dynamics in Wuhan, China, of novel coronavirus-infected pneumonia. N Engl J Med 2020; 382(13): 1199-1207. doi: 10.1056/NEJMoa2001316.

10. Amirian ES. Journal pre-proof potential fecal transmission of SARS-CoV-2: Current evidence and implications for public health. Int J Infect Dis 2020. [in press]. doi: 10.1016/j.ijid.2020.04.057

11. Antibody responses to SARS-CoV-2 in patients of novel coronavirus disease 2019. [online]. Available from: https://pubmed.ncbi.nlm.nih.gov/32221519/.

12. Hou H, Wang T, Zhang B et al. Detection of IgM and lgG antibodies in patients with coronavirus disease 2019. Clin Transl Immunol 2020; 9(5): e01136. doi: 10.1002/cti2.1136. 13. Gudbjartsson DF, Helgason A, Jonsson $\mathrm{H}$ et al. Spread of SARS-CoV-2 in the Icelandic population. N Engl J Med 2020. [ in press]. doi: 10.1056/NEJMoa2006100.

14. Guan WJ, Ni ZY, Hu Y et al. Clinical characteristics of coronavirus disease 2019 in China. N Engl J Med 2020. [in press]. doi: 10.1056/NEJMoa2002032.

15. Richardson S, Hirsch JS, Narasimhan M et al. Presenting characteristics, comorbidities, and outcomes among 5700 patients hospitalized with COVID-19 in the New York City area. JAMA 2020. [in press]. doi: 10.1001/jama.2020.6775.

16. Liu Y, Yan LM, Wan L et al. Viral dynamics in mild and severe cases of COVID-19. Lancet Infect Dis 2020. [in press]. doi: 10.1016/S1473-3099(20)30232-2.

17. Cohen AN, Kessel B. False positives in reverse transcription PCR testing for SARS-CoV-2. [online]. Available from: https://www.medrxiv.org/content/10.1101/ 2020.04.26.20080911v1.full.pdf.

18. In vitro antiviral activity and projection of optimized dosing design of hydroxychloroquine for the treatment of severe acute respiratory syndrome coronavirus 2 (SARS-CoV-2). [online]. Available from: https://pubmed.ncbi.nlm.nih.gov/32150618/?from_single_result $=32150618 \&$ expanded_search_query $=32150$ 618

19. Gautret P, Lagier J-C, Parola P et al. Hydroxychloroquine and azithromycin as a treatment of COVID-19: results of an open-label non-randomized clinical trial. Int J Antimicrob Agents 2020. [in press]. doi: 10.1016/j.ijantimicag.2020.105949. 